\title{
Macroevolutionary analysis of the tempo of diversification in snappers and fusiliers (Percomorpha: Lutjanidae)
}

\author{
Bruno Frédérich ${ }^{1,2, *} \&$ Francesco Santini ${ }^{3}$ \\ ${ }^{1}$ Laboratoire de Morphologie Fonctionnelle et Evolutive, AFFISH Research Center, \\ Université de Liège, 4000 Liège, Belgique. \\ ${ }^{2}$ Laboratoire d'Océanologie, MARE Center, Université de Liège, 4000 Liège, Belgique. \\ ${ }^{3}$ Associazione Italiana per lo Studio della Biodiversitá, 56100 Pisa, Italy. \\ ${ }^{*}$ Corresponding author: bruno.frederich@ulg.ac.be \\ Email: francesco.santini@alumni.utoronto.ca
}

\begin{abstract}
The percomorph fish family Lutjanidae (snappers and fusiliers) includes about 135 reefdwelling species, mainly confined to tropical and subtropical marine waters. The great majority of snappers are active predators feeding on fishes or crustaceans, even though some species, including the fusiliers (Caesioninae), have evolved zooplanktivory. Lutjanids show a great diversity of habitat preferences, based on depth segregation and distribution across reef and associated habitats (e.g., mangroves, seagrass beds, estuaries). In spite of their great ecological and economic importance little is known about the tempo of evolution in this group. The present study provides the most comprehensive molecular phylogeny to date for lutjanids, including $70 \%$ of extant species and 19 of the 21 currently described genera. We time-calibrated our molecular tree using the oldest described lutjanid fossils, and show how this group most likely originated during the Late Cretaceous or Early Paleocene. Lutjanids experienced a significant radiation during the Late Eocene and Early Oligocene, in contrast to a pattern of Late Oligocene/Miocene radiation observed in many other reef-associated groups. The time-tree allows us to investigate the tempo of diversification, and our results suggest a variation in the rate of speciation during the evolution of the major clade formed by "lutjanins and caesionins". Variation in diet and life history strategies could explain this clade-specific dynamic, although future phylogenetic comparative studies combining additional ecological and morphological data are needed to test this hypothesis.
\end{abstract}

KEY WORDS. Lutjanus, phylogeny, ecological radiation, lineage diversification, molecular clock.

Frédérich B. \& Santini F. 2017. Macroevolutionary analysis of the tempo of diversification in snappers and fusiliers (Percomorpha: Lutjanidae). Belgian Journal of Zoology 147 (1): 17-35. https://doi.org/10.26496/bjz.2017.2

\section{Introduction}

Snappers and fusiliers (Lutjanidae) include about 135 extant species of medium-sized to large fishes (FROESE \& PAULY 2016; ESCHMEYER et al. 2016). Lutjanidae represents a successful radiation of reefand mangrove-associated percomorphs in marine and brackish coastal waters across the tropical and subtropical oceans. Many species of snappers are the target of commercial fisheries in tropical areas, and they are considered one of the most important components of artisanal fisheries across many tropical countries (ALLEN 1985). 


\section{TABLE 1}

Taxonomic diversity of Lutjanidae. The total number of species (data obtained from IWATSUKI et al. 2015; Froese \& PAULY 2016; EsChMEYER et al. 2016) and the number of species included in our time-calibrated phylogeny $(\mathrm{N})$ are provided. Numbers in brackets refer to the total number of species included in each subfamily.

\begin{tabular}{|c|c|c|c|}
\hline Taxon & Genus & $\mathbf{N}_{\text {TOTAL }}$ & $\mathbf{N}$ \\
\hline \multirow[t]{4}{*}{ Apsilinae (12) } & Apsilus & 2 & 1 \\
\hline & Lipocheilus & 1 & - \\
\hline & Paracaesio & 8 & 2 \\
\hline & Parapristipomoides & 1 & - \\
\hline \multirow[t]{5}{*}{ Etelinae (20) } & Aphareus & 2 & 2 \\
\hline & Aprion & 1 & 1 \\
\hline & Etelis & 5 & 4 \\
\hline & Pristipomoides & 11 & 7 \\
\hline & Randallichthys & 1 & 1 \\
\hline \multirow[t]{2}{*}{ Paradichthyinae (2) } & Symphorus & 1 & 1 \\
\hline & Symphorichthys & 1 & 1 \\
\hline \multirow[t]{6}{*}{ Lutjaninae (78) } & Hoplopagrus & 1 & 1 \\
\hline & Lutjanus & 71 & 54 \\
\hline & Macolor & 2 & 2 \\
\hline & Ocyurus & 1 & 1 \\
\hline & Pinjalo & 2 & 2 \\
\hline & Rhomboplites & 1 & 1 \\
\hline \multirow[t]{4}{*}{ Caesioninae (23) } & Caesio & 9 & 4 \\
\hline & Dipterygonotus & 1 & 1 \\
\hline & Gymnocaesio & 1 & 1 \\
\hline & Pterocaesio & 12 & 7 \\
\hline TOTAL & & 135 & 94 \\
\hline
\end{tabular}

The family Lutjanidae is composed of 21 genera distributed into five subfamilies: Apsilinae, Etelinae, Paradicichthyinae, Lutjaninae and Caesioninae (Table 1 - JOHNSON 1993; MILLER \& CRIBB 2007). With 71 known species, the genus Lutjanus includes most of the taxonomic diversity of the family (IWATSUKI et al. 2015; FROESE \& PAULY 2016). Snappers are active predators, with most species feeding on fishes or large crustaceans using their powerful caniniform teeth (ALLEN 1985). Both the fusiliers, a lineage of open-water dwellers, as well as several additional snappers with a relatively slender, fusiform body shape and a forked caudal fin (e.g., Ocyurus, Paracaesio, Pristipomoides, Rhomboplites) have, however, evolved a zooplanktivorous diet (ALLEN 1985).

There is a strong variation of habitat preferences among lutjanids. Indeed, most species live in shallow waters less than $100 \mathrm{~m}$ deep (e.g., Aprion, Lutjanus, Symphorichthys and Symphorus), while others, such as Paracaesio, are found at intermediate depth $(100-200 \mathrm{~m})$, and the species of the genera Etelis and Aphareus live in waters up to $500 \mathrm{~m}$ below the surface (NEWMAN \& WILLIAMS 1996). Numerous species of Lutjanus experience ontogenetic habitat shifts, and some are mangrove- or estuarine-dependent for the completion of their juvenile phase (e.g., NAGELKERKEN et al. 2000; ABURTO-OROPEZA et al. 2009). During growth these species of Lutjanus show an ontogenetic shift from mangroves and estuaries to deeper, offshore coral reef environments. However some species, such as Lutjanus griseus (Linnaeus, 1758), may also occur in estuarine mangroves when adults (NAGELKERKEN et al. 2000). 
In spite of the ecological and economic importance of this group, we currently do not have a denselysampled phylogeny for this clade. All studies published to date include only a handful of lutjanid species, often from geographically restricted regions or from restricted clades (SARVER et al. 1996; ZHOU et al. 2004; ZHU et al. 2006; GOLD et al. 2015; WAKEFIELD et al. 2016; ANDREWS et al. 2016). For example, MILLER \& CRIBB (2007) investigated the relationships among 27 species of Indo-Western Pacific (IWP) snappers while the studies of GOLD et al. (2011) included 20 species, 13 of which originated from the Western Atlantic or Eastern Pacific. The most extensive molecular phylogeny of snappers published to date only includes 43 species, representing around $32 \%$ of the extant diversity of the family (CHU et al. 2013). Moreover, none of these studies took advantage of the fossil record of lutjanids to produce a timescale of snapper evolution. Only GoLD et al. (2011) used a strict clock approach and a fixed rate of molecular evolution inferred from studies of previous groups to produce a time-tree for the lutjanid subclade of their study. In addition to the absence of a large-scale phylogenetic hypothesis of lutjanid intra-relationships, we are also lacking a macroevolutionary study looking at the tempo of evolutionary diversification of this group.

In the present study, we used a supermatrix approach to assemble a dataset containing four loci for 94 species of lutjanids (i.e., $70 \%$ of the extant diversity). Our molecular phylogeny was then timecalibrated using the oldest described lutjanid fossils and used as a framework to explore the tempo of lineage diversification.

\section{Materials and Methods}

\section{Data acquisition and sampling}

Our molecular data set includes 94 species of Lutjanidae representing 19 of the 21 currently described genera (Tables 1, S1), with only the two monotypic genera Lipocheilus and Parapristipomoides missing. We used the PhyLoTa browser version 1.5 (SANDERSON et al. 2008) to obtain sequences for four loci that had the highest number of sequences available for lutjanids: the nuclear Ragl and the mitochondrial cox1, Cytb, and 16s (Table S1). As the current version of PhyLoTa is based on release 194 of GenBank (from February 15, 2013), we added more recent sequences for the species in our sampling directly from GenBank.

It is not currently known with certainty which percomorph lineage is the sister group of the lutjanids. Most recent studies investigating teleost fish deep level relationships suggest the existence of a group formed by Lutjanidae, Haemulidae (grunts) and Malacanthidae (tilefishes) (BETANCUR-R et al. 2013; NEAR et al. 2013; RABOSKY et al. 2013). We thus selected as outgroups two species of Haemulidae, the group that most frequently appears as the sister taxon to lutjanids (BETANCUR-R et al. 2013; NEAR et al. 2013; RABOSKY et al. 2013).

\section{Phylogenetic analyses}

We used the MUSCLE aligner (EDGAR 2004) available in MEGA 6 (TAMURA et al. 2013) to align the individual gene datasets using the default setting, and then visually inspected the alignments to ensure that these would be biologically accurate. We trimmed the 3' and 5' ends of the alignments in order to minimize the amount of missing data, and concatenated the four loci using Mesquite 3.01 (MADDISON \& MADDISON 2015). Our final data matrix consisted of 1371 base pairs (bp) for Ragl, $600 \mathrm{bp}$ for $16 \mathrm{~s}$, $651 \mathrm{bp}$ for coxl, and $954 \mathrm{bp}$ for Cytb, for a total of 3576 nucleotides. We used PartitionFinder v1.1.1 (LANFEAR et al. 2012) to identify the optimal set of partitions of the data and select the best fitting models of sequence evolution for each of these from the pool of models implemented in BEAST 1.8 (DRUMMOND \& RAMBAUT 2007) using Bayes factor scores (BIC). We did not include models that have both the gamma parameter and the proportion of invariant sites parameter, as this last parameter is already accounted for by the gamma (YANG 2006). The partitions and selected models are listed in Table 2. 
TABLE 2

Models of sequence evolution selected by PartitionFinder under the corrected Akaike Information Criterion scores (AICc).

\begin{tabular}{ccc}
\hline Best model & Subset partitions & Subset sites \\
\hline TrN+G & cox1_1, cytb_1 & $1-651 \backslash 3,652-1605 \backslash 3$ \\
HKY+I & cox1_2, cytb_2 & $2-651 \backslash 3,653-1605 \backslash 3$ \\
TrN+G & cox1_3 & $3-651 \backslash 3$ \\
GTR+G & cytb_3 & $654-1605 \backslash 3$ \\
SYM+G & $16 s$ & $1606-2205$ \\
& & $2206-3576 \backslash 3,2207-$ \\
HKY+I & rag1_1, rag1_2 & $3576 \backslash 3$ \\
HKY+G & rag1_3 & $2208-3576 \backslash 3$ \\
\hline
\end{tabular}

We performed Bayesian analyses using MrBayes 3.2 (RONQUIST et al. 2012) after each partition had been assigned the model selected by PartitionFinder (LANFEAR et al. 2012). The models not implemented by MrBayes, such as variations of the TrN, were replaced by the closest model (GTR). We ran two analyses for 25 million generations each with four chains (three heated, one cold) and sampling every 1000 generations. We visually inspected the trace files in Tracer 1.6 (DRUMMOND \& RAMBAUT 2007) to verify that the chains had reached convergence. After discarding the first 12.5 million generations as burnin, we combined the remaining trees to obtain a $50 \%$ majority rule consensus tree.

In order to use the molecular dataset to infer a time-calibrated phylogeny, we used the uncorrelated lognormal priors enforced in BEAST 1.8 (DRUMMOND \& RAMBAUT 2007). The oldest known lutjanid fossil that has been referred to the crown snappers is Hypsocephalus atlanticus Swift \& Ellwood, 1972 from the Operculinoides ocalanus-Asterocyclina Zone of the Crystall River Formation, Ocala group, which has been referred to the uppermost Late Eocene of Florida (SWIFT \& ELLWOOD 1972). These sediments date to the very end of the Eocene and the beginning of the Oligocene. We thus use the Eocene-Oligocene boundary to set a minimum age of 33.9 Ma for this fossil, which is thought to be a close relative of the extant Hoplopagrus guntheri Gill, 1862. As Hoplopagrus is recovered within the clade "Lutjanus", and the relationships among some of the most basal nodes within this clade are not strongly supported, we used this fossil calibration to set a minimum age on the clade "Lutjanus". Currently there are six fossils from the Middle Eocene deposits of Bolca (Italy, dated at $\sim 50 \mathrm{Ma}$; CARNEVALE et al. 2014) that have been identified as Lutjanidae (BANNIKOV 2006), even though their placement has not yet been supported by a comparative morphological phylogenetic study and some of these fossils may lack synapomorphies of extant lutjanids identified by JOHNSON (1980) (G. Carnevale, pers. comm.). For the purpose of our analysis we treat these fossils as stem lutjanids, providing an age of $50 \mathrm{Ma}$ for the soft upper boundary on this calibration. We also assigned a prior to the root of our tree. As there are no fossils that can convincingly date the split between lutjanids and haemulids, we used a normal distribution with a mean age of $67 \mathrm{Ma}$ and an SD of $10 \mathrm{Ma}$. This choice produces a 95\% probability that lutjanids and haemulids separated between $50 \mathrm{Ma}$, age of the putative stem lutjanids from Bolca, and 83.5 Ma, age of the Calcari di Melissano Formation from Nardò (Italy), which contains several records of fossil percomorphs (see supplementary material in CHEN et al. 2014 for justification of the age).

All partitions were assigned the same model selected by PartitionFinder (LANFEAR et al. 2012), and a birth-death prior with incomplete sampling was assigned to the rates of cladogenesis. We ran four sets of analyses with 50 million generations each, and sampling every 10000 generations. We used Tracer 1.6 (DRUMMOND \& RAMBAUT 2007) to inspect the chains for convergence, which we interpreted to have 
occurred when the ESS for all parameters was over 200. As the chains reached convergence very rapidly, we removed the first $10 \%$ of the trees as burnin, used LogCombiner to merge the remaining trees, and used TreeAnnotator (DRUMMOND \& RAMBAUT 2007) to obtain a consensus time-tree.

\section{Lineage diversification}

We explored the tempo of lineage diversification by computing the gamma $(\gamma)$ statistic, which indicates the extent to which a phylogeny differs from branching events expected under a constant-rate process. A negative $\gamma$ value indicates that the internal nodes of the tree are closer to the root, supporting a model of early diversification. We then assessed the significance of $\gamma$ statistic using the Monte Carlo constant rates (MCCR) test of PYBUS \& HARVEY (2000), which accounts for incomplete taxon sampling. We also assessed the fit of four models of clade accumulation to the branching times in our phylogeny. We compared two constant rate models (Yule and birth-death) to two density-dependent speciation rate models, predicting slowdowns in the tempo of diversification [density-dependent exponential (DDX) and density-dependent logistic (DDL) following RABOSKY \& LOVETTE 2008]. We used Akaike's Information Criterion (AIC) scores and weights to compare the fit of the models. A $\triangle \mathrm{AICc}$ value of four or more was taken as an indication of support for one model over the others following BURNHAM \& ANDERSON (2002). The MCCR test, the $\gamma$ statistic and diversification model fitting were computed using the LASER package (Version 2.4.1; RABOSKY 2006) for R (R DEVELOPMENT CORE TEAM, 2015).

\section{Results}

\section{Phylogenetic analyses and divergence time estimates}

The topologies of the Bayesian analyses confirm the non-monophyly of lutjanids without the inclusion of the caesionins, a result already shown by previous molecular studies (MILLER \& CRIBB 2007). A number of highly supported clades are identified, even though some of the deeper nodes of the tree have poor posterior probability (PP) support, and some polytomies appear toward the more recent part of the phylogeny (Fig. 1). Several of the traditional genera, including Lutjanus (the richest genus in terms of species number; Table 1), are non-monophyletic.

In our analysis, Apsilus dentatus Guichenot, 1853, Paracaesio, Valenciennes, 1830, Etelis, Randallichthys, Aphareus and Pristipomoides are grouped together and are found to be sister taxa of the remaining lutjanids (Fig. 1). Within this subclade including seven different genera, Apsilus dentatus and Paracaesio are sister taxa to a subclade that includes Aprion virescens + Randallichthys + Etelis as well as a paraphyletic Pristipomoides, which includes Aphareus. Within the other subclade, Symphorichthys and Symphorus form a well-supported monophyletic assemblage sister to all remaining lutjanids, i.e., the lutjanins and caesionins (here referred as "lutjanins + caesionins" clade). The next lineage to branch off includes Lutjanus adetii (Castelnau, 1873) and Lutjanus sebae (Cuvier, 1816), sister to Pinjanlo pinjalo (Bleeker, 1850), several additional species of Lutjanus [L. timoriensis (Quoy \& Gaimard, 1824), L. sanguineus (Cuvier, 1828), L. erythropterus Bloch, 1790 and L. malabaricus (Bloch \& Schneider, 1801)] and Pinjalo lewisi Randall, Allen \& Anderson, 1987 (clade A, Fig. 1). Hoplopagrus guentherii is then shown to be the sister taxon to a large clade, combining clade B and clade C (Fig. 1). Lutjanus gibbus (Forsskål, 1775), Macolor and the caesionins (Caesio, Pterocaesio, Dipterygonotus balteatus and Gymnocaesio gymnoptera, with both Caesio and Pterocaesio shown to be non-monophyletic) form clade B. The clade C (Fig. 1) includes several lineages that form the bulk of the diversity within Lutjanus, and among which the relationships are relatively unresolved. One of these subclades also includes the last two remaining genera within our sampling: Ocyurus and Rhomboplites.

The topologies produced by the Beast analyses closely match those of the MrBayes analyses, although they provide increased resolution towards the youngest nodes of the tree. In the analyses (Fig. 2), the stem age of the lutjanids is $\sim 62 \mathrm{Ma}$ while the age of crown lutjanids is $\sim 54 \mathrm{Ma}$ (45-66 Ma 95\% Highest Posterior Density, HPD). The Apsilus, Paracaesio, Aprion, Etelis, Randallichthys, Aphareus and Pristipomoides clade is Middle Eocene in age (47 Ma, 37-58 Ma 95\% HPD). Within this clade, 


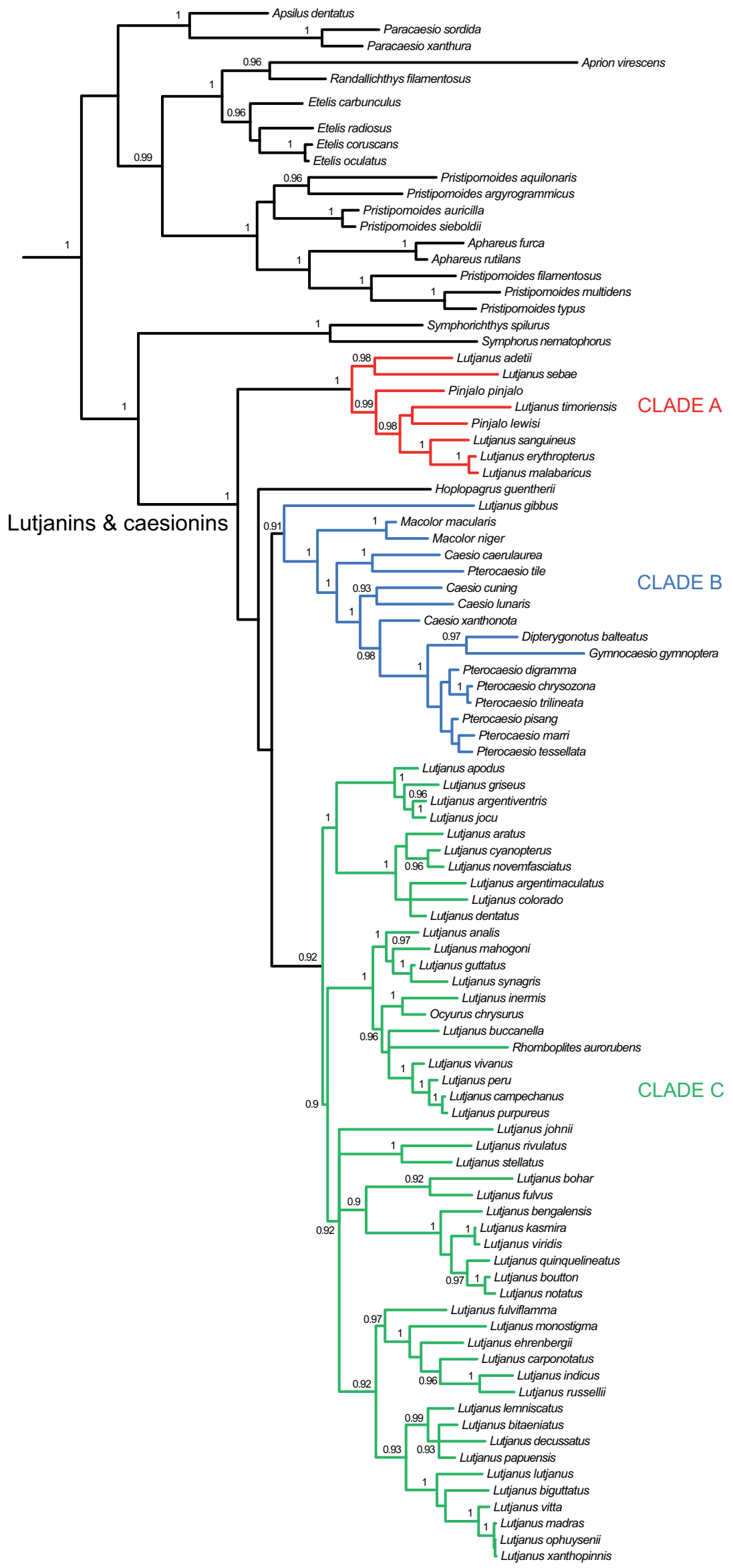


TABLE 3

Results from fitting models of lineage diversification. The models are ranked from best to worst, according to AIC scores and Akaike weights (wtAIC). $\triangle \mathrm{AIC}$ scores indicate the difference between the candidate model and the best-fitting model. The initial speciation rate $(r)$ and, if applicable, an additional model-specific parameter, are provided.

\begin{tabular}{llccccc}
\hline Clade & model & AIC & $\Delta$ AIC & wtAIC & $r$ & Parameter \\
\hline Entire time-tree & DDL & 20.38 & 0.00 & 0.62 & 0.097 & 165.9 \\
& DDX & 22.68 & 2.30 & 0.20 & 0.134 & 0.194 \\
& Pure birth (Yule) & 23.44 & 3.06 & 0.13 & 0.066 & - \\
& Birth-death & 25.44 & 5.06 & 0.05 & 0.066 & 0.000 \\
\hline Clade "lutjanins \& caesionins" & DDL & 19.55 & 0.00 & 0.63 & 0.132 & 109.5 \\
& DDX & 21.08 & 1.53 & 0.30 & 0.253 & 0.333 \\
& Pure birth (Yule) & 24.58 & 5.03 & 0.05 & 0.079 & - \\
& Birth-death & 26.58 & 7.03 & 0.02 & 0.079 & 0.000 \\
\hline
\end{tabular}

the paraphyletic Pristipomoides is $32 \mathrm{Ma}$ (25-41 Ma 95\% HPD), while Etelis is $15 \mathrm{Ma}$ (9-21 Ma 95\% HPD). The Symphorichthys + Symphorus clade dates to 21 Ma (13-31 Ma 95\% HPD) and splits from the "lutjanins + caesionins" clade around $48 \mathrm{Ma}$ (40-58 Ma 95\% HPD). The crown age of the paraphyletic Lutjanus clade is $\sim 37 \mathrm{Ma}(30-45 \mathrm{Ma} 95 \% \mathrm{HPD})$. The crown fusilier subclade originates in the Early Miocene, $23 \mathrm{Ma}(18-29 \mathrm{Ma} 95 \% \mathrm{HPD})$, while the group that includes the majority of the species currently assigned to Lutjanus splits from Hoplopagrus around $32 \mathrm{Ma}$ (26-39 Ma 95\% HPD) and starts radiating towards the end of the Oligocene, $\sim 27 \mathrm{Ma}$ (21-33 Ma 95\% HPD).

\section{Lineage diversification}

The MCCR test finds some evidence for a slowdown in the diversification rate during the evolution of Lutjanidae but this result is not significant $(\gamma=-2.72, P=0.16)$. The comparison of the fit of the diversification models fails to find strong support for constant rate models over diversity-dependent ones, and a pure birth model of diversification cannot be rejected (Table 3).

Lutjaninae and Caesioninae form a clade (Figs 1-2) including most of the taxonomic diversity of Lutjanidae ( $\mathrm{N}=101$ species, i.e., $75 \%$ of the family). Thus, we have repeated the comparative analyses on this major clade. We find evidence for a slowdown in the diversification rate during the evolution of this clade $(\gamma=-2.35, P=0.04)$, a result confirmed by visual inspection of the lineage-through-time plot (Fig. 3). Accordingly, the two density-dependent models (DDL and DDX) are the best-supported models and together account for $93 \%$ of the Akaike weight (Table 3). This result from models fitting suggests that high rates of lineage diversification occurred during the early history of the "lutjanins \& caesionins" clade, followed by a subsequent slowdown in diversification rate.

Figure 1 (opposite page) - Bayesian phylogenetic hypothesis inferred with MrBayes 3.2.6. Values above branches indicate posterior probabilities (PP) over 0.90. Clades A, B \& C from the "lutjanins and caesionins" are illustrated in different colours. 


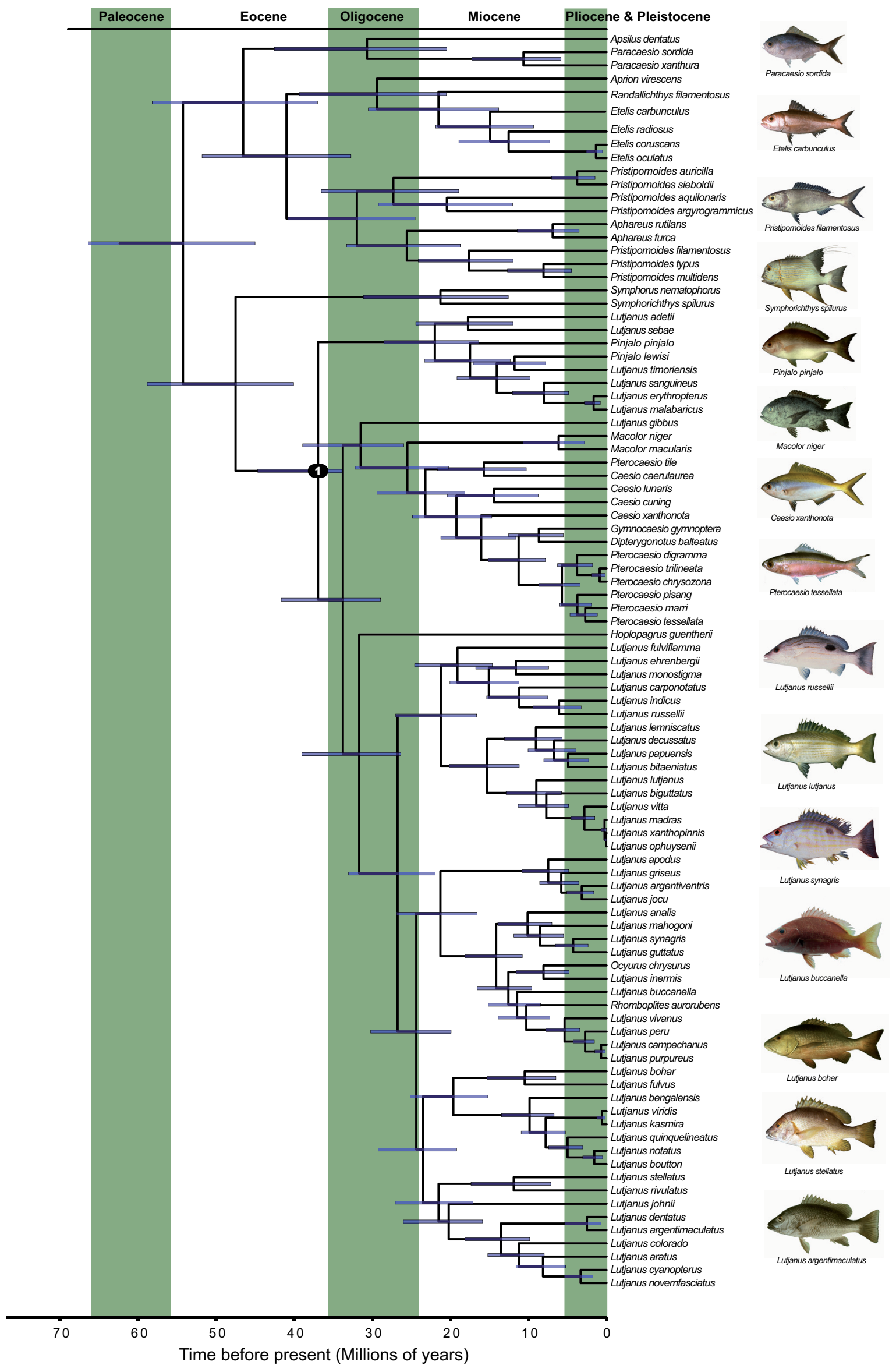




\section{Discussion}

\section{Phylogeny, fossil record and timescale of lutjanids}

Our phylogenetic study based on the analysis of $\sim 3.6 \mathrm{~kb}$ of mitochondrial and nuclear DNA sequences provides (1) the first densely-sampled molecular tree of snappers and allies, and (2) the first timescale for the entire group based on fossil lutjanid calibration points. Our analyses infer results that are congruent with the previous - and more limited - studies in showing that zooplanktivorous caesionins originated within the subfamily Lutjaninae, a group known to include species that mostly feed on fishes or benthic crustaceans (MILLER \& CRIBB 2007). We also corroborate earlier findings that the most species-rich genus, Lutjanus, is not monophyletic (MILlER \& CRIBB 2007; GOLD et al. 2011). Our phylogenetic study shows that several additional genera (e.g., Pristipomoides, Pinjalo, Caesio, Pterocaesio) are in need of revision due to their non-monophyly. Unfortunately the fossil record of the lutjanids remains relatively understudied, when compared to that of several other reef-associated groups that are abundant in the Bolca deposits (e.g., acanthurids, BLOT \& TYLER 1990; TYLER 1999, 2005a, 2005b; TYLER \& BANNIKOV 2000; pomacentrids, COOPER \& SANTINI 2016; tetraodontiforms, TYLER \& SANTINI 2002; SANTINI \& TYLER 2003). The fish assemblage from Monte Bolca, Italy (Ypresian, $50 \mathrm{Ma}$ ) includes at least six species that have been tentatively identified as lutjanids: Ottaviania mariae Sorbini, 1983 and O. leptacanthus (Agassiz, 1839), Veranichthys ventralis (Agassiz, 1839), Goujetia crassispina (Agassiz, 1839), Lessinia horrenda Bannikov \& Zorzin, 2014 and Lessinia sp. (BANNIKOV 2006; CARNEVALE et al. 2014). The lack of a thorough morphological analysis of lutjanid synapomorphies (JOHNSON 1980) within these fossils currently prevents us from knowing with certainty whether they are all stem lineages or if some of them might fall within the crown snapper clade. This fact may have some important implications for the molecular dating. The oldest fossil that can currently be assigned with certainty to the crown lutjanids is the Late Eocene Hypsocephalus atlanticus from Florida, found in deposits that are about 16 Ma younger than Bolca (SWIFT \& ELLWOOD 1972). The molecular timescale that we infer when the fossil of Hypsocephalus is used to provide a minimum age for the clade "Lutjanus" suggests an Early Paleogene origin of the snappers and allies, and of their radiation $(\sim 62$ stem age, $\sim 54$ Ma crown age). These ages are in fairly good agreement with the Early Eocene estimates for the split between lutjanids and haemulids recovered by large-scale teleost dating analyses (BETANCUR-R. et al. 2013; NEAR et al. 2013).

It is clear that crown lutjanids had originated by the Middle Eocene, and had already undergone a significant diversification during the Late Eocene and Early Oligocene period. Our results show that a large fraction of the extant lineages originated during this interval. Thus, snappers do not appear to have experienced the same extent of Late Oligocene/Early Miocene radiations that were identified in other reef-associated groups, such as pufferfishes, triggerfishes and allies (ALFARO et al. 2007; DORNBURG et al. 2011; SANTINI et al. 2013a, 2013b), butterflyfishes (COWMAN \& BELLWOOD 2011) and parrotfishes (Alfaro et al. 2009; KAZANCIOGLU et al. 2009; CowMAN \& Bellwood 2011).

\section{Diversification of lutjanids}

A Yule model with constant rate of speciation may explain the tempo of diversification across the family. However the gamma statistic, the MCCR test and the comparison of lineage diversification models support a slowdown in the diversification rate across the "lutjanins + caesionins" clade (Fig. 3). A shift to accelerated rates of evolution during the early radiation of this major group could explain this cladespecific dynamic.

Figure 2 (opposite page) - BEAST chronogram of lutjanids. Blue bars indicate 95\% HPD. The fossil calibration applied to the clade "Lutjanus" is indicated by the \#1. Fish images modified under Creative Commons license from original photographs by J. E. Randall (retrieved from www.fishbase.org). 
The "lutjanins + caesionins" clade includes $75 \%$ of the extant diversity of Lutjanidae and groups most of the lutjanids living in shallow waters and reef-associated habitats (NEWMAN \& WILLIAMS 1996). As the great majority of studies of modern reef fish families did not recover a signal of slowdown in diversification rate from time-calibrated molecular phylogenies (e.g., COWMAN \& BELLWOOD 2011; DORNBURG et al. 2011; FRÉDÉRICH et al. 2013; but see seabreams and porgies - SANTINI et al. 2014), there seems to be evidence that the evolutionary history of this lutjanid subclade may show a different dynamic to that of other coral reef fish groups. While the data presently available do not allow us to more thoroughly test this, we hypothesize that lineages of Lutjanus and other closely related genera may have avoided the pattern of severe Oligocene extinctions that probably affected other reef-associated groups (COWMAN \& BELlwood 2011; BellwoOd et al. 2016). Such extinction avoidance may be due either to some aspects of their ecology or because they were able to occupy some kind of refugia, such as estuarine and brackish areas that many extant species of Lutjanus are known to inhabit, at least at the juvenile stage (NAGELKERKEN et al. 2000).

An early divergence among macrohabitat specialists could explain the ecological radiation in Lutjanidae, as already suggested for parrotfishes by STREELMAN et al. (2002). There is a strong variation of habitat preferences among lutjanids. The first steps of lineage divergence are probably associated with depth segregation: Randallichthys, Aphareus, Pristipomoides, Etelis are bottom-dwelling fishes usually encountered below $200 \mathrm{~m}$ depth; Paracaesio are characteristic of intermediate depth (100-200 m); and the others live in shallow waters less than $100 \mathrm{~m}$ (e.g., Aprion, Lutjanus, Symphorichthys and Symphorus) (Newman \& Williams 1996; Froese \& PAUly 2016). Lutjanus and closely related genera (Symphorichthys, Symphorus, Hoplopagrus) are known to differ in their distribution across the continental shelf (NEWMAN \& WILLIAMS 1996), and a review of the available literature on their distribution allowed us to partially illustrate such an ecological radiation. The subclades grouping species of Lutjanus are mainly characterized by species living either on the inshore, or the mid shelf or the outer shelf of reef environments. Lutjanus kasmira (Forsskål, 1775), L. bohar (Forsskål, 1775), L. fulvus (Forster, 1801) and L. quinquelineatus (Bloch, 1790) form a group of species mainly associated with the outer reef slope (LyTHGOE et al. 1994; NEWMAN \& WiLliams 1996). On the other hand, the clade including $L$. sebae, L. malabaricus, L. erythropterus groups taxa living in the mid shelf and the inner reef (NEWMAN \& WILLIAMS 1996). Moreover, the visual pigments of the species of Lutjanus

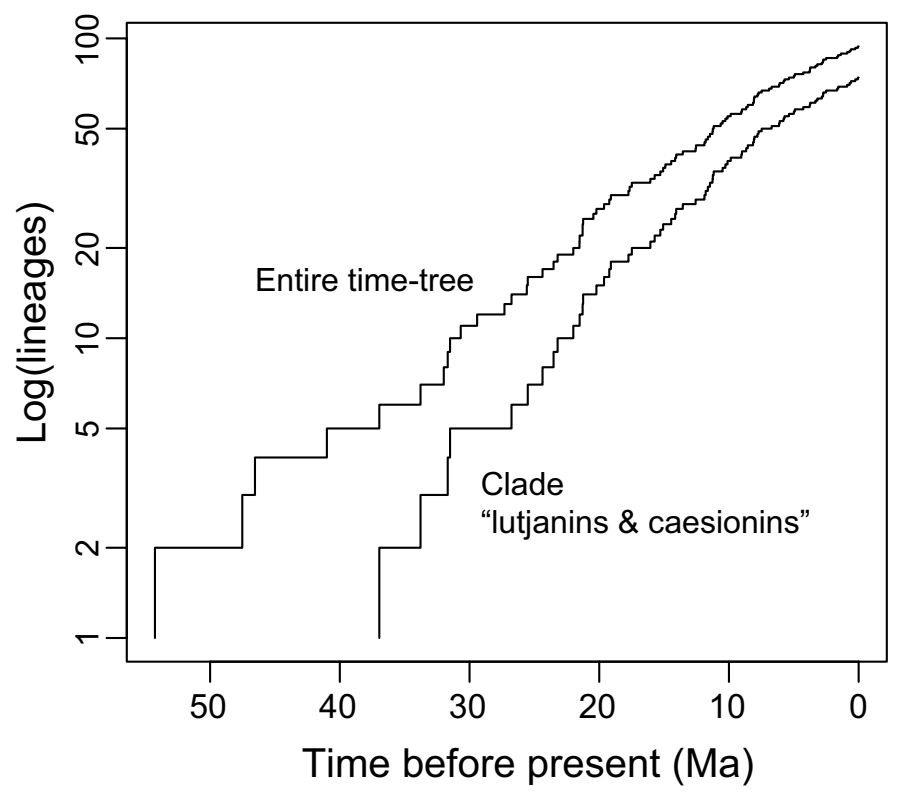

Figure 3 - Lineages through time plot. The figure illustrates the accumulation of lutjanid diversity across the entire tree, as well as the accumulation of lineages within the clade formed by "lutjanins and caesionins". The number of lineages was log-transformed (y-axis). 
living in the clear blue water of the outer reefs differ from their relatives living in "green" and turbid inshore waters (LYTHGOE et al. 1994). Directional selection on visual systems could thus have driven an early divergence of macrohabitats in the species of Lutjanus, a hypothesis that would clearly require future testing.

The species of Lutjanus not only vary in their habitat preference at the adult stage, but also differ in their life history strategies. Indeed, various Lutjanus experience ontogenetic habitat shifts (e.g., NAGELKERKEN et al. 2000; ABURTO-OROPEZA et al. 2009). In some species, juveniles grow in estuaries, mangroves or seagrass beds, then migrate onto adjacent coral reefs (COCHERET DE LA MORINIÈRE et al. 2003). In others, the juvenile phase is completed around a reef environment similar to that inhabited by their adults. To date, this ontogenetic trait is still poorly documented for a large number of species represented in our phylogeny but the available data allow us to formulate some hypotheses. The juveniles of the species of Lutjanus from clade A (e.g., L. sebae, L. erythropterus and L. malabricus) are rarely encountered in mangrove estuaries (NEWMAN, 1995) while the great majority of the species of Lutjanus from clade C frequently complete their juvenile phase in estuaries, mangroves or seagrass beds (LYTHGOE et al. 1994; NEWMAN \& Williams 1996; NAGELKERKEN et al. 2000; MARTINEZ-ANDRADE 2003; MONTEIRO, et al. 2009; Pimentel \& JOYEUX 2010). This observation suggests a shift to mangrove-, seagrass bedand estuarine-dependence for the clade $\mathrm{C}$ of Lutjanus, although this assumption certainly needs further investigations. The turbid waters of these three types of habitats provide a great abundance of food for fishes, and decrease the foraging efficiency of predators (NAGELKERKEN et al. 2000). Such ecological factors may boost the fitness of fishes adapted to these environments, such as some species of Lutjanus, and ultimately may explain their evolutionary success. The ontogenetic habitat shift observed in Lutjanus is also usually associated with diet shifts (COCHERET DE LA MORINÈRE et al. 2003; BERKSTRÖM et al. 2013). The relation between habitat and diet shifts could vary among species (BERKSTRÖM et al. 2013), reducing competition and allowing coexistence of close relatives.

In addition to habitat partitioning and variation in life history strategies, trophic strategies vary among subclades. Most lutjanids feed on fishes and crabs (ALLEN 1985) but the trophic shift to zooplanktivory observed in Caesioninae could also be responsible for promoting lineage diversification (LOBATO et al. 2014). Finally, other factors could sustain speciation. A large body of marine biogeographic literature strongly suggests that allopatric speciation events have certainly had an important role in driving diversification in many reef-associated fishes (SANTINI \& WINTERBOTTOM 2002; BRIGGS \& BowEN 2012; LiTSIOS et al. 2014), and there is no reason to think that snappers were not affected by this phenomenon.

\section{Conclusions}

We provide the first densely-sampled molecular phylogeny of Lutjanidae. Our new tree corroborates some of the findings of earlier studies. The caesionins are nested within the lutjanins, suggesting that zooplanktivory evolved from ancestors that had a piscivorous or crustacean-based diet. Several traditional genera, such as the speciose Lutjanus that includes over half of the species of snappers, are non-monophyletic. Our time-tree shows that lutjanids most likely separated from their sister group (haemulids) during the Late Cretaceous to Early Paleocene, and subsequently split into two clades during the Paleocene/Early Eocene. Lutjanids experienced significant radiation during the Late Eocene and Early Oligocene, in contrast to a pattern of mostly Late Oligocene/Miocene radiation observed in many other reef-associated groups. Comparative methods indicate a constant rate of speciation across the family but we found some evidence of a variation in the tempo of cladogenesis during the evolution of the major clade "lutjanins and caesionins". We argue that lutjanids may have experienced an early ecological radiation due to habitat partitioning. Differences in diet and life history strategies have also probably influenced the diversification of the largest clade, formed by lutjanins and caesionins. However additional research combining ecological and morphological data, as well as phylogenetic comparative methods, is clearly needed to test these hypotheses. 


\section{Acknowledgements}

We thank G. Carnevale (University of Torino) for advice regarding the status of the Bolca fossils, as well as for pointing out to us the lutjanid fossil from Florida. We also want to thank the branch editor and three anonymous reviewers for the useful comments made when reviewing this manuscript. The phylogenetic analyses were run on XSEDE thanks to funding by XSEDE grant TG-DEB140025 to FS. BF was funded by the "Fonds National de la Recherche Scientifique of Belgium" (F.R.S-FNRS). BF is currently a post-doctoral researcher from BELSPO (Belgian Science Policy).

\section{References}

Aburto-Oropeza O., Dominguez-Guerrero I., Cota-Nieto J. \& Plomozo-Lugo T. (2009). Recruitment and ontogenetic habitat shifts of the yellow snapper (Lutjanus argentiventris) in the Gulf of California. Marine Biology 156: 2461-2472. https://doi.org/10.1007/s00227-009-1271-5

Alfaro M.E., SANTini F. \& BRock C.D. (2007). Do reefs drive diversification in marine teleosts? Evidence from the pufferfish and their allies (order Tetraodontiformes). Evolution 61: 2104-2126. https://doi.org/10.1111/j.1558-5646.2007.00182.x

Alfaro M.E., BRock C.D., BANBURY B.L. \& WAINWRIGHT P.C. (2009). Does evolutionary innovation in pharyngeal jaws lead to rapid lineage diversification in labrid fishes? BMC Evolutionary Biology 9: 255. https://doi.org/10.1186/1471-2148-9-255

AlLEN G.R. (1985). FAO species catalogue. Snappers of the world. An annotated and illustrated catalogue of lutjanid species known to date. FAO Fisheries Synopsis No. 125, Vol. 6, 208 pp.

Andrews K.R., Williams A.J., Fernandez-Silva I., Newman S.J., Copus J.M., WaKefield C.B., RANDALL J.E. \& BOWEN B.W. (2016). Phylogeny of deepwater snappers (Genus Etelis) reveals a cryptic species pair in the Indo-Pacific and Pleistocene invasion of the Atlantic. Molecular Phylogenetics and Evolution 100: 361-371. https://doi.org/10.1016/j.ympev.2016.04.004

BANNIKOV A.F. (2006). Fishes from the Eocene of Bolca, northern Italy, previously classified in the Sparidae, Serranidae and Haemulidae (Perciformes). Geodiversitas 28 (2): 249-275.

Bellwood D.R., Goatley C.H.R. \& Bellwood O. (2016). The evolution of fishes and corals on reefs: form, function and interdependence. Biological Reviews 92 (2): 878-901. https://doi.org/10.1111/ brv. 12259

BERKSTRÖM C., JÖRgENSEN T. \& HELlSTRÖM M. (2013). Ecological connectivity and niche differentiation between two closely related fish species in the mangrove-seagrass-coral reef continuum. Marine Ecology Progress Series 477: 201-215. https://doi.org/10.3354/meps10171

Betancur-R. R., Broughton R.E., Wiley E.O., CARPenter K., López J.A., Li C., Holcroft N.I., Arcila D., SAnciangco M., Cureton II J.C., Zhang F., Buser T., CAMPbell M.A., Ballesteros J.A., Roa-Varon A., Willis S., Borden W.C., Rowley T., Reneau P.C., Hough D.J., Lu G., Grande T., Arratia G. \& Ortí G. (2013). The Tree of Life and a new classification of bony fishes. PLoS Currents Tree of Life. Edition 1, 18 April 2013. https://doi.org/10.1371/currents.tol.53ba26640df0ccae $\underline{\mathrm{e} 75 \mathrm{bb} 165 \mathrm{c} 8 \mathrm{c} 26288}$

Blot J. \& TYLER J.C. (1990). New genera and species of fossil surgeonfishes and their relatives (Acanthuroidei, Teleostei) from the Eocene of Monte Bolca, Italy, with application of the Blot formula to both fossil and recent forms. Studi e Ricerche sui Giacimenti Terziari di Bolca 6: 13-92.

BRIGGS J.C. \& BOWEN B.W. (2012). A realignment of marine biogeographic provinces with particular reference to fish distributions. Journal of Biogeography 39: 12-30. https://doi.org/10.1111/j.1365$\underline{2699.2011 .02613 . x}$ 
BURNHAM K.P. \& ANDERSON D.R. (2002). Model selection and multimodel inference: a practical information-theoretic approach. Springer, New York.

Carnevale G., Bannikov A.F., Marramà G., Tyler J.C. \& Zorzin R. (2014). The Pesciara-Monte Postale Fossil-Lagerstätte: fishes and other vertebrates. Rendiconti della Società Paleontologica Italiana 4: $37-63$.

Chen W.-J., Santini F., Carnevale G., Chen J.-N., Liu S.-H., Lavoué S. \& Mayden R.L. (2014). New insights on early evolution of spiny-rayed fishes (Teleostei: Acanthomorpha). Frontiers in Marine Sciences 53: 1. https://doi.org/10.3389/fmars.2014.00053

Chu C., Rizman-Idid M. \& Ching C.V. (2013). Phylogenetic relationships of selected genera of Lutjanidae inferred from mitochondrial regions, with a note on the taxonomic status of Pinjalo pinjalo. Ciencias Marinas 39 (4): 349-361. https://doi.org/10.7773/cm.v39i4.2287

Cocheret de la Morinière E., Pollux B.J.A., NAgelkerken I., Hemminga M.A., Huiskes A.H.L. \& VAN DER VELDE G. (2003). Ontogenetic dietary changes of coral reef fishes in the mangrove-seagrassreef continuum: Stable isotopes and gut-content analysis. Marine Ecology Progress Series 246: 279289. https://doi.org/10.3354/meps246279

CoOper W.J \& SANTINI F. (2016). A revised damselfish taxonomy with a description of the tribe Microspathodontini (giant damselfishes). In: FréDÉRICH B. \& PARMENTIER E. (eds) Biology of Damselfishes: 15-30. CRC Press, Boca Raton.

COWMAN P.F. \& BELLwOOD D.R. (2011). Coral reefs as drivers of cladogenesis: Expanding coral reefs, cryptic extinction events, and the development of biodiversity hotspots. Journal of Evolutionary Biology 24: 2543-2562. https://doi.org/10.1111/j.1420-9101.2011.02391.x

Dornburg A., Sidlauskas B., Santini F., Sorenson L., Near T.J. \& Alfaro M.E. (2011). The influence of an innovative locomotor strategy on the phenotypic diversification of triggerfish (family: Balistidae). Evolution 65: 1912-1926. https://doi.org/10.1111/j.1558-5646.2011.01275.x

DRUMMOND A.J. \& RAMBAUT A. (2007). BEAST: Bayesian evolutionary analysis by sampling trees. BMC Evolutionary Biology 7: 214. https://doi.org/10.1186/1471-2148-7-214

EDGAR R.C. (2004). MUSCLE: multiple sequence alignment with high accuracy and high throughput. Nucleic Acids Research 32: 1792-1797. https://doi.org/10.1093/nar/gkh340

ESCHMEYER W.N., FRICKE R. \& VAN DER LAAN R. (2016). Catalog of Fishes. Available from http:// www.calacademy.org/scientists/projects/catalog-of-fishes [accessed 31 Aug. 2016].

Frédérich B., Sorenson L., SAntini F., Slater G.J. \& Alfaro M.E. (2013). Iterative ecological radiation and convergence during the evolutionary history of damselfishes (Pomacentridae). The American Naturalist 181: 94-113. https://doi.org/10.1086/668599

Froese R. \& Pauly D. (2016). FishBase. Available from www.fishbase.org [accessed 30 Sep. 2016].

Gold J.R., Voelker G. \& Renshaw M.A. (2011). Phylogenetic relationships of tropical western Atlantic snappers in subfamily Lutjaninae (Lutjanidae: Perciformes) inferred from mitochondrial DNA sequences. Biological Journal of the Linnean Society 102: 915-929. https://doi.org/10.1111/j.10958312.2011.01621.x

Gold J.R., Willis S.C., Renshaw M.A., Buentello A., Walker JR. H.J., PuRitz J.B., Hollenbeck C.M. \& VoelKer G. (2015). Phylogenetic relationships of tropical eastern Pacific snappers (Lutjanidae) inferred from mitochondrial DNA sequences. Systematics and Biodiversity 13 (6): 596-607. https://doi. org/10.1080/14772000.2015.1078857 
IWATSUKI Y., TANAKA F. \& ALLEN G.R. (2015). Lutjanus xanthopinnis, a new species of snapper (Pisces: Lutjanidae) from the Indo-west Pacific, with a redescription of Lutjanus madras (Valenciennes 1831). Journal of the Ocean Science Foundation 17: 22-42.

JoHnson G.D. (1980). The limits and relationships of the Lutjanidae and associated families. Bulletin of the Scripps Institution of Oceanography 24: 1-114.

JOHNSON G.D. (1993). Percomorph phylogeny: progress and problems. Bulletin of Marine Science 52: $3-28$.

KaZAnCioglu E., Near T.J., Hanel R. \& Wainwright P.C. (2009). Influence of sexual selection and feeding functional morphology on diversification rate of parrotfishes (Scaridae). Proceedings of the Royal Society B-Biological Sciences 276: 3439-3446. https://doi.org/10.1098/rspb.2009.0876

Lanfear R., Calcott B., Ho S.Y.W. \& Guindon S. (2012). PartitionFinder: combined selection of partitioning schemes and substitution models for phylogenetic analyses. Molecular Biology and Evolution 29: 1695-1701. https://doi.org/10.1093/molbev/mss020

Litsios G., Pearman P.B., LanterbecQ D., Tolou N. \& Salamin N. (2014). The radiation of the clownfishes has two geographical replicates. Journal of Biogeography 41: 2140-2149. https://doi. org $/ 10.1111 / \mathrm{jbi} .12370$

Lobato F.L., Barneche D.R., Siqueira A.C., Liedke A.M.R., Lindner A., Pie M.R., Bellwood D.R. \& FLOETER S.R. (2014). Diet and diversification in the evolution of coral reef fishes. PLoS ONE 9 (7): e102094. https://doi.org/10.1371/journal.pone.0102094

Lythgoe J.N., Muntz W.R.A., Partridge J.C., Shand J. \& Williams D.M. (1994). The ecology of the visual pigments of snappers (Lutjanidae) on the Great Barrier Reef. Journal of Comparative Physiology A 174: 461-467. https://doi.org/10.1007/BF00191712

MADDISON W.P. \& MADDISON D.R. (2015). Mesquite: a modular system for evolutionary analysis, version 3.01. Available from http://www.mesquiteproject.org [accessed 24 Apr. 2017].

MARTINEZ-ANDRADE F. (2003) A comparison of life histories and ecological aspects among snappers (PISCES: Lutjanidae). Louisiana State University, Department of Oceanography and Coastal Sciences, $\mathrm{PhD}$ Thesis, $194 \mathrm{pp}$.

Miller T.L. \& CRIBB T.H. (2007). Phylogenetic relationships of some common Indo-Pacific snappers (Perciformes: Lutjanidae) based on mitochondrial DNA sequences, with comments on the taxonomic position of the Caesioninae. Molecular Phylogenetics and Evolution 44: 450-460. https://doi. org/10.1016/j.ympev.2006.10.029

MonteIro D.P., GiARrizzo T. \& ISAAC V. (2009). Feeding ecology of juvenile dog snapper Lutjanus jocu (Bloch and Shneider, 1801) (Lutjanidae) in intertidal mangrove creeks in Curuçá estuary (Northern Brazil). Brazilian Archives of Biology and Technology 52: 1421-1430. https://doi.org/10.1590/S1516$\underline{89132009000600014}$

NAgelkerken I., van der Velde G., Gorissen M.W., Meijer G.J., VAN'T Hof T. \& den Hartog C. (2000). Importance of mangroves, seagrass beds and the shallow coral reef as a nursery for important coral reef fishes, using a visual census technique. Estuarine, Coastal and Shelf Science 51: 31-44. https://doi.org/10.1006/ecss.2000.0617

Near T.J., Dornburg A., Eytan R.I., Keck B., Smith W.L., Kuhn K.L., Moore J.A., Price S.A., BurbrinK F.T., FriedMAN M. \& WAINWRIght P.C. (2013). Phylogeny and tempo of diversification in the superradiation of spiny-rayed fishes. Proceedings of the National Academy of Sciences of the United States of America 110: 12738-12743. https://doi.org/10.1073/pnas.1304661110 
Newman S.J. (1995). Spatial variability in the distribution, abundance, growth, mortality and age structures of tropical snappers (Pisces: Lutjanidae) in the Central Great Barrier Reef, Australia. James Cook University, Department of Marine Biology, PhD Thesis, 325 pp.

NeWMAN S.J. \& WiLLiams D.M. (1996). Variation in reef associated assemblages of the Lutjanidae and Lethrinidae at different distances offshore in the central Great Barrier Reef. Environmental Biology of Fishes 46: 123-138. https://doi.org/10.1007/BF00005214

PIMENTEL C.R. \& JoYeUX J.-C. (2010). Diet and food partitioning between juveniles of mutton Lutjanus analis, dog Lutjanus jocu and lane Lutjanus synagris snappers (Perciformes: Lutjanidae) in a mangrovefringed estuarine environment. Journal of Fish Biology 76: 2299-2317. https://doi.org/10.1111/j.1095$\underline{8649.2010 .02586 . x}$

PyBus O.G. \& HARVEY P.H. (2000). Testing macro-evolutionary models using incomplete molecular phylogenies. Proceedings of the Royal Society, Series B-Biological Sciences 267: 2267-2272. https:// doi.org/10.1098/rspb.2000.1278

RABOSKY D.L. (2006). LASER: a maximum likelihood toolkit for detecting temporal shifts in diversification rates from molecular phylogenies. Evolutionary Bioinformatics 2: 247-250.

RABosky D.L. \& LovetTe I.J. (2008). Density-dependent diversification in North American wood warblers. Proceedings of the Royal Society Series B-Biological Sciences 275: 2363-2371. https://doi. org/10.1098/rspb.2008.0630

Rabosky D.L., Santini F., Eastman J., Smith S.A., Sidlauskas B., Chang J. \& Alfaro M.E. (2013). Rates of speciation and morphological evolution are correlated across the largest vertebrate radiation. Nature Communications 4: 1958. https://doi.org/10.1038/ncomms2958

R DeVElopment CORE TEAm (2015). R: A language and environment for statistical computing. Vienna, Austria. Available from http://www.R-project.org [accessed 25 Aprl. 2017].

Ronquist F., Teslenko M., van der Mark P., Ayres D.L., Darling A., Höhna S., Larget B., Liu L., Suchard M.A. \& Huelsenbeck J.P. (2012). MrBayes 3.2: Efficient bayesian phylogenetic inference and model Choice across a large model space. Systematic Biology 61: 539-542. https://doi. org/10.1093/sysbio/sys029

Sanderson M.J., Boss D., Chen D., Cranston K.A. \& Wehe A. (2008). The PhyLotA Browser: processing GenBank for molecular phylogenetics research. Systematic Biology 57: 335-346. https://doi. org $/ 10.1080 / 10635150802158688$

SANTINI F. \& TYLER J.C. (2003). A phylogeny of the families of fossil and extant tetraodontiform fishes (Acanthomorpha, Tetraodontiformes), Upper Cretaceous to recent. Zoological Journal of the Linnean Society 139: 565-617. https://doi.org/10.1111/j.1096-3642.2003.00088.x

SANTINI F. \& WinTERBOtTOM R. (2002). Historical biogeography of Indo-western Pacific coral reef biota: is the Indonesian region a centre of origin? Journal of Biogeography 29: 189-205. https://doi. org/10.1046/j.1365-2699.2002.00669.x

Santini F., Nguyen M., Sorenson M., Waltzek T.B., Alfaro J.W.L., Eastman J.M. \& Alfaro M.E. (2013a). Do habitat shifts drive diversification in teleost fishes? An example from the pufferfishes (Tetraodontidae). Journal of Evolutionary Biology 26: 1003-1018. https://doi.org/10.1111/jeb.12112

SANTINI F., SORENSON L. \& AlfARO M.E. (2013b). A new multi-locus timescale reveals the evolutionary basis of diversity patterns in triggerfishes and filefishes (Balistidae, Monacanthidae; Tetraodontiformes). Molecular Phylogenetics and Evolution 69:165-176. https://doi.org/10.1016/j.ympev.2013.05.015

SANTINI F., CARNEVAlE G. \& SORENSON L. (2014). First multi-locus timetree of seabreams and porgies (Percomorpha: Sparidae). Italian Journal of Zoology 81: 55-71. https://doi.org/10.1080/11250003.201 $\underline{3.878960}$ 
SARVER S.K., Freshwater D.W. \& WALSh P. (1996). Phylogenetic relationships of western Atlantic snappers (family Lutjanidae) based on mitochondrial DNA sequences. Copeia 1996: 715-721.

Streelman J.T., Alfaro M.E., Westneat M.W., Bellwood D.R. \& KArL S.A. (2002). Evolutionary history of the parrotfishes: biogeography, ecomorphology, and comparative diversity. Evolution 56: 961-971. https://doi.org/10.1111/j.0014-3820.2002.tb01408.x

SwiFT C. \& ElLwood B. (1972). Hypsocephalus atlanticus, a new genus and species of lutjanid fish from marine Eocene limestones of Northern Florida. Contributions in Science 230: 1-29.

Tamura K., Stecher G., Peterson D., Filipski A. \& Kumar S. (2013). MegA6: Molecular Evolutionary Genetics Analysis version 6.0. Molecular Biology and Evolution 30: 2725-2729. https:// doi.org/10.1093/molbev/mst197

TYLER J.C. (1999). A new genus and species of surgeonfish (Acanthuridae) with a unique dorsal-fin pterygiophore arrangement from the Eocene of Monte Bolca, Italy. Studi e Ricerche sui Giacimenti Terziari di Bolca 7: 245-256.

TYLER J.C. (2005a). Redescription and basal phylogenetic placement of the acanthurid surgeonfish Gazolaichthys vestenanovae from the Eocene of Monte Bolca, Italy (Perciformes; Acanthuroidea). Studi e Ricerche sui Giacimenti Terziari di Bolca 11: 97-117.

TYLER J.C. (2005b). A new genus for the surgeon fish Acanthurus gaudryi De Zigno 1887 from the Eocene of Monte Bolca, Italy, amorphologically primitive basal taxon of Acanthuridae (Acanthuroidea, Perciformes). Studi e Ricerche sui Giacimenti Terziari di Bolca 11: 149-163.

TYleR J.C. \& BANNIKOV A.F. (2000). A new species of the surgeon fish genus Tauichthys from the Eocene of Monte Bolca, Italy (Perciformes, Acanthuridae). Bollettino del Museo Civico di Storia Naturale di Verona 24: 29-36.

TYLER J.C. \& SANTINI F. (2002). Review and reconstructions of the tetraodontiform fishes from the Eocene of Monte Bolca, Italy, with comments on related Tertiary taxa. Studi e Ricerche sui Giacimenti Terziari di Bolca 9: 47-119.

Wakefield C.B., Moore G.I., Bertram A.E., Snow M. \& Newman S.J. (2016). Extraordinary capture of a Randall's snapper Randallichthys filamentosus in the temperate south-eastern Indian Ocean and its molecular phylogenetic relationship within the Etelinae. Journal of Fish Biology 88: 735-740. https://doi.org/10.1111/jfb.12809

YANG Z. (2006). Computational Molecular Evolution. Oxford University Press, Oxford.

Zhou F., JiAng S., Su T. \& LU J. (2004). Comparative study of mtDNA 16S rRNA gene fragments among six Lutjanus fish. Journal of Fisheries Science 11: 99-103.

Zhu S.-H., YANG Y.-C., Shen X.-Q., Zou J.-X., Zheng W.-J., Yu H.-W. \& HuANG B. (2006). Phylogenetic relationships of Lutjanus inferred from mitochondrial cytochrome b sequences. Acta Zoologica Sinica 52: 514-521.

Manuscript received: 30 May 2016

Manuscript accepted: 9 November 2016

Published on: 14 July 2017

Branch editor: Tom Artois 
Table S1

List of species included in this study with GenBank accession number of sequences used for phylogenetic analyses.

\begin{tabular}{|c|c|c|c|c|c|}
\hline \# & Taxon & $16 s$ & $\operatorname{cox} 1$ & Cytb & Rag1 \\
\hline 1 & Haemulon sciurus (Haemulidae) & JQ938959 & JQ841208 & AF240747 & JX189823 \\
\hline 2 & Plectorhinchus orientalis (Haemulidae) & NC_027097 & NC_027097 & NC_027097 & HQ676673 \\
\hline 3 & Aphareus furca & DQ784722 & HQ676753 & DQ784746 & HQ676633 \\
\hline & Aphareus rutilans & & HQ561493 & KU954262 & \\
\hline 5 & Aprion virescens & DQ784723 & JF492869 & DQ784747 & \\
\hline 6 & Apsilus dentatus & & HQ162409 & HQ162458 & \\
\hline 7 & Caesio caerulaurea & DQ784724 & GU804898 & AF381273 & \\
\hline 8 & Caesio cuning & DQ784725 & KC970453 & AF240749 & KF141193 \\
\hline 9 & Caesio lunaris & & JQ349804 & & EU167813 \\
\hline 10 & Caesio xanthonota & & JF492995 & & \\
\hline 11 & Dipterygonotus balteatus & & KF489569 & AF381270 & \\
\hline 12 & Etelis carbunculus & & EF609353 & KF920552 & \\
\hline 13 & Etelis coruscans & & JF493464 & KF920529 & \\
\hline 14 & Etelis oculatus & & GU225202 & HQ162420 & \\
\hline 15 & Etelis radiosus & & KU954260 & KU954277 & \\
\hline 16 & Gymnocaesio gymnoptera & & HQ561514 & & EU167837 \\
\hline 17 & Hoplopagrus guentherii & & KJ557448 & KJ570970 & \\
\hline 18 & Lutjanus adetii & DQ784727 & EF609393 & DQ784751 & \\
\hline 19 & Lutjanus analis & AY857938 & JQ842198 & HQ162432 & EF095662 \\
\hline 20 & Lutjanus apodus & JQ741057 & GU225357 & HQ162435 & \\
\hline 21 & Lutjanus aratus & & KJ557442 & KJ570964 & \\
\hline 22 & Lutjanus argentimaculatus & DQ784728 & JF493820 & EF025494 & EU627659 \\
\hline 23 & Lutjanus argentiventris & AY947839 & GU440385 & KJ570955 & \\
\hline 24 & Lutjanus bengalensis & FJ171339 & FJ171339 & FJ171339 & EU627660 \\
\hline & Lutjanus biguttatus & & KF009607 & & JX189829 \\
\hline & Lutjanus bitaeniatus & & KC130849 & & \\
\hline 27 & Lutjanus bohar & DQ784729 & JF952787 & DQ784753 & \\
\hline & Lutjanus boutton & & KT718540 & & \\
\hline & Lutjanus buccanella & & JQ842205 & HQ162438 & \\
\hline & Lutjanus campechanus & AY857940 & HQ162373 & AY374294 & \\
\hline & Lutjanus carponotatus & DQ78473 & EF609395 & DQ784754 & \\
\hline & Lutjanus colorado & HQ127652 & GU186970 & KJ570961 & \\
\hline
\end{tabular}




\begin{tabular}{|c|c|c|c|c|c|}
\hline \# & Taxon & $16 s$ & $\operatorname{cox} 1$ & Cytb & Rag1 \\
\hline 33 & Lutjanus cyanopterus & & GQ329867 & HQ162441 & \\
\hline 34 & Lutjanus decussatus & AF247445 & KC130837 & AF240750 & \\
\hline 35 & Lutjanus dentatus & & & & EU167846 \\
\hline 36 & Lutjanus ehrenbergii & & HQ149873 & & \\
\hline 37 & Lutjanus erythropterus & GQ265897 & GQ265897 & GQ265897 & EU627661 \\
\hline 38 & Lutjanus fulviflamma & DQ784731 & JF493832 & EF376177 & EU627662 \\
\hline 39 & Lutjanus fulvus & DQ784732 & JQ431896 & AY501366 & EU627672 \\
\hline 40 & Lutjanus gibbus & DQ784733 & GU805121 & DQ784757 & \\
\hline 41 & Lutjanus griseus & AY857944 & GU225643 & HQ162426 & KF141274 \\
\hline 42 & Lutjanus guttatus & & KJ557427 & KJ570949 & \\
\hline 43 & Lutjanus indicus & & KF830923 & & \\
\hline 44 & Lutjanus inermis & & KJ557430 & KJ570952 & \\
\hline 45 & Lutjanus jocu & AY857943 & FJ998476 & HQ162444 & \\
\hline 46 & Lutjanus johnii & KJ643926 & KJ643926 & KJ643926 & EU627663 \\
\hline 47 & Lutjanus kasmira & FJ416614 & FJ416614 & FJ416614 & EU627664 \\
\hline 48 & Lutjanus lemniscatus & & EF609397 & & \\
\hline 49 & Lutjanus lutjanus & & FJ237812 & & EU627665 \\
\hline 50 & Lutjanus madras & & JN208427 & & \\
\hline 51 & Lutjanus mahogoni & & GU225372 & HQ162445 & EU182625 \\
\hline 52 & Lutjanus malabaricus & FJ824741 & FJ824741 & FJ824741 & EU627666 \\
\hline 53 & Lutjanus monostigma & DQ784735 & KC130845 & DQ784759 & \\
\hline 54 & Lutjanus notatus & & HQ561531 & KJ570959 & \\
\hline 55 & Lutjanus novemfasciatus & AY958620 & GU440386 & KJ570965 & \\
\hline 56 & Lutjanus ophuysenii & & EU600098 & EF376179 & EU627671 \\
\hline 57 & Lutjanus papuensis & & HM422401 & & \\
\hline 58 & Lutjanus peru & AY947840 & HQ162412 & HQ162461 & \\
\hline 59 & Lutjanus purpureus & KJ907227 & JX297373 & & KJ907361 \\
\hline 60 & Lutjanus quinquelineatus & DQ784736 & JF952789 & DQ784760 & \\
\hline 61 & Lutjanus rivulatus & & JF493845 & DQ484045 & \\
\hline 62 & Lutjanus russellii & EF514208 & EF514208 & EF514208 & EU627667 \\
\hline 63 & Lutjanus sanguineus & & JF493850 & DQ484049 & JN106042 \\
\hline 64 & Lutjanus sebae & FJ824742 & FJ824742 & FJ824742 & EU627668 \\
\hline 65 & Lutjanus stellatus & DQ444483 & EU600133 & EF376163 & EU627670 \\
\hline 66 & Lutjanus synagris & AY857939 & GU225376 & HQ162429 & \\
\hline 67 & Lutjanus timoriensis & & KJ202176 & & \\
\hline
\end{tabular}


FRÉDÉRICH B. \& SANTINI F., Phylogeny of Lutjanidae

\begin{tabular}{|c|c|c|c|c|c|}
\hline \# & Taxon & $16 s$ & $\operatorname{cox} 1$ & Cytb & Rag1 \\
\hline 68 & Lutjanus viridis & & KJ557434 & KJ570956 & \\
\hline 69 & Lutjanus vitta & DQ784739 & EF609402 & EF376181 & EU627669 \\
\hline 70 & Lutjanus vivanus & & HQ162397 & HQ162448 & \\
\hline 71 & Lutjanus xanthopinnis & & LC071442 & & \\
\hline 72 & Macolor macularis & & KF930094 & & \\
\hline 73 & Macolor niger & DQ784740 & KF489639 & DQ784764 & \\
\hline 74 & Ocyurus chrysurus & AY857942 & FJ998488 & HQ162451 & JX189830 \\
\hline 75 & Paracaesio sordida & & GU805104 & & \\
\hline 76 & Paracaesio xanthura & & JF494063 & & \\
\hline 77 & Pinjalo lewisi & & KP856802 & KR007727 & \\
\hline 78 & Pinjalo pinjalo & & JN208390 & & EU167860 \\
\hline 79 & Pristipomoides aquilonaris & DQ532943 & HQ162403 & HQ162457 & \\
\hline 80 & Pristipomoides argyrogrammicus & & KF930322 & & \\
\hline 81 & Pristipomoides auricilla & & JQ432043 & & \\
\hline 82 & Pristipomoides filamentosus & & DQ885120 & JQ083093 & \\
\hline 83 & Pristipomoides multidens & KF430626 & KF430626 & KF430626 & \\
\hline 84 & Pristipomoides sieboldii & & GU805046 & & \\
\hline 85 & Pristipomoides typus & & EF609438 & & \\
\hline 86 & Pterocaesio chrysozona & & JQ350291 & & \\
\hline 87 & Pterocaesio digramma & LC099463 & KF009653 & & \\
\hline 88 & Pterocaesio marri & DQ784742 & GU804914 & DQ784766 & \\
\hline 89 & Pterocaesio pisang & DQ784743 & KJ202192 & DQ784767 & KF141343 \\
\hline 90 & Pterocaesio tessellata & & KJ202193 & & \\
\hline 91 & Pterocaesio tile & AP004447 & AP004447 & AP004447 & \\
\hline 92 & Pterocaesio trilineata & & HQ561504 & & \\
\hline 93 & Randallichthys filamentosus & & KP954301 & & \\
\hline 94 & Rhomboplites aurorubens & AY857941 & HQ162406 & AY294198 & KF141349 \\
\hline 95 & Symphorichthys spilurus & DQ784744 & FJ584135 & DQ784768 & \\
\hline 96 & Symphorus nematophorus & DQ784745 & KC130829 & DQ784769 & EU167876 \\
\hline
\end{tabular}

